\title{
Pengaruh Sistem Pengukuran Kinerja dan Disiplin Kerja terhadap Kinerja Pegawai Bea dan Cukai dalam Pengawasan Rokok Ilegal
}

\author{
Abbas Mansyur a,1,*, Yulianto ${ }^{\mathrm{b}, 2}$ \\ ${ }^{a}$ Institut Ilmu Sosial dan Manajemen STIAMI, Jakarta \\ ${ }^{\mathrm{b}}$ Institut Ilmu Sosial dan Manajemen STIAMI, Jakarta \\ 1 abbas_mansyur@yahoo.co.id *; ${ }^{2}$ yuliantobc2013@gmail.com \\ * corresponding author
}

\section{ARTICLE INFO}

ARTICLE HISTORY

Received Oktober 2019

Revised Desember 2019

Accepted Februari 2020

Keywords

Performance Measurement

System,

Discipline, and

Performance.

\begin{abstract}
According to law enforcement in excise sector, customs and excise officers are supervise on illegal cigarettes. The main purpose is to diminish illegal cigarettes and optimizing revenue in excise from cigarettes sector. Enforcement was intensively on illegal cigarettes throughout 2014-2016, shown by 902 cases increase to 2.409 cases. In contrary, illegal cigarettes increased throughout 2014-2016 from 11,73\% to 12,14\%. Those illegal cigarettes also causing affect to revenue in excise from cigarettes sector, primarily in 2016 while target realization 100,02\% only, because revenue was collecting Rp137.969.225.430.00 from target set at Rp137.935.634.471.520. Discrepancy between sum of cases on illegal cigarettes, illegal cigarettes and revenue in excise from cigarettes sector becomes an interesting research topic. This research employs survey method which population are customs and excise officers work on enforcement unit in Indonesia. Sampling method is probability on cluster sampling to collect quantitative data and analyzed those data summarize using descriptive and verification approach to find out the effect of performance measurement system and work discipline to performance of customs and excise officers in supervision illegal cigarettes. This research concludes performance measurement system and work discipline give a positive and significant effect to customs and excise officers' performance in supervision and reducing illegal cigarettes and optimizing revenue in excise from cigarettes sector.
\end{abstract}

\section{PENDAHULUAN}

Direktorat Jenderal Bea dan Cukai (DJBC) adalah organisasi sektor publik yang dituntut harus mampu membangun tata kelola pemerintah yang baik, salah satunya dengan menerapkan sistem pengukuran kinerja berbasis Ballaced Scorecards agar kinerja organisasi dan kinerja pegawai dapat diukur dengan baik, sehingga fungsi pengawasan, penegakan hukum, pelayanan, dan penerimaan dapat dilaksanakan secara efektif dan efisien.

Cukai adalah pungutan negara yang dikenakan terhadap barang-barang yang mempunyai sifat dan karakteristik tertentu. Rokok adalah objek cukai karena sifat dan karakteristiknya memberi dampak negatif bagi kesehatan masyarakat dan lingkungan hidup, sehingga komsumsinya harus dikendalikan dengan cara membayar cukai dan diawasi peredarannya. Kebijakan pemerintah dalam mengendalikan konsumsi rokok menjadi sebuah dilema ketika di satu sisi harus dapat mengurangi jumlah konsumsi rokok, namun demikian di sisi lainnya pemerintah masih mengandalkan cukai rokok untuk membiayai belanja negara, sehingga dalam Undang-Undang Anggaran Penerimaan dan Belanja Negara (UU APBN) yang ditetapkan setiap tahun, pemerintah selalu meningkatkan target penerimaan negara dari sektor cukai rokok.

Kebijakan pengendalian konsumsi rokok menjadi sulit dilaksanakan karena beberapa faktor, salah satunya beredarnya rokok ilegal di Indonesia. Dalam upaya menegakkan hukum Undang-Undang Nomor 11 Tahun 1995 Tentang Cukai sebagaimana telah diubah dengan Undang-Undang Nomor 39 Tahun 2007, DJBC melakukan pengawasan dan penindakan secara tegas terhadap pelaku kejahatan rokok ilegal dengan tujuan untuk mengurangi jumlah peredaran rokok ilegal dan mengoptimalkan penerimaan cukai rokok. 

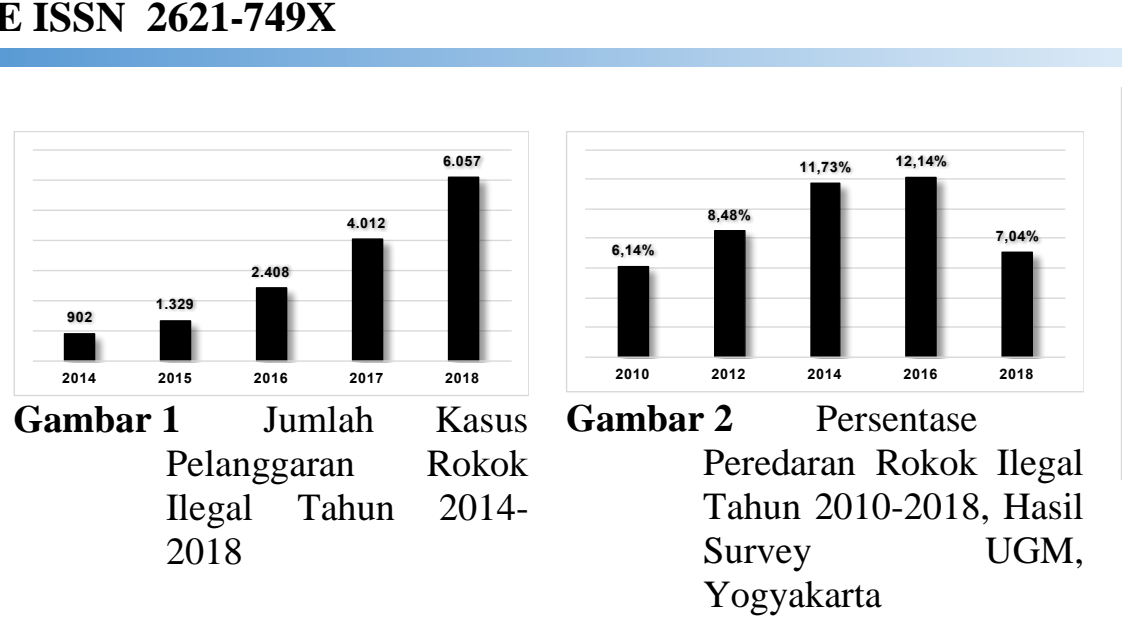

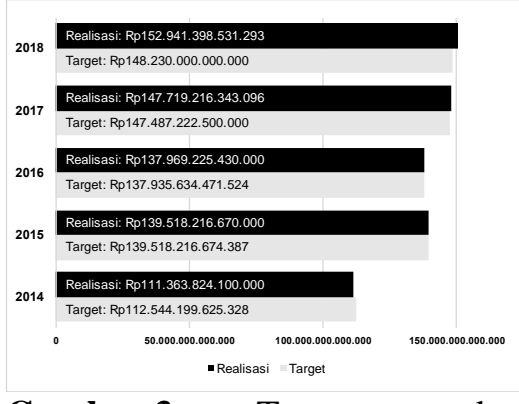

Gambar 3 Target dan Realisasi Penerimaan Cukai Rokok Tahun 2014-2018

Pengawasan rokok ilegal telah dilaksanakan secara masif. Kinerja pengawasan pada tahun 20142015 meningkat dari 902 kasus menjadi 1.329 kasus (Gambar 1), namun hal tersebut belum dapat mengurangi jumlah rokok ilegal, karena dari hasil Survei Cukai Rokok Ilegal yang dilakukan Universitas Gajah Mada (UGM) Yogyakarta pada tahun 2014 dan 2016, persentase rokok ilegal yang beredar di Indonesia meningkat dari 11,73\% menjadi 12,74\% (Gambar 2), dan menyebabkan penerimaan cukai rokok tidak optimal. Realisasi penerimaan cukai rokok pada tahun 2016 hanya 100,02\% dengan capaian sebesar Rp137.969.225.430.000 dari target yang ditetapkan dalam UU APBN Tahun 2016 sebesar Rp137.935.634.471.524 (Gambar 3).

Dalam membangun tata kelola pemerintah yang baik, DJBC melakukan perubahan organisasi dengan membentuk unit kerja yang khusus menangani fungsi kepatuhan internal dengan tujuan untuk membentuk budaya organisasi yang lebih baik melalui peningkatan disiplin kerja Pegawai Bea dan Cukai sebagai faktor pendorong agar kinerja pengawasan rokok ilegal menjadi lebih optimal.

Kinerja pengawasan rokok ilegal, hasil Survei Cukai Rokok Ilegal yang dilakukan UGM, Yogyakarta, dan kinerja penerimaan cukai rokok pada tahun 2016 adalah sebuah fenomena, sehingga penulis tertarik meneliti Pengaruh Sistem Pengukuran Kinerja dan Disiplin Kerja terhadap Kinerja Pegawai Bea dan Cukai dalam Pengawasan Peredaran Rokok Ilegal. Tujuannya adalah: a. Untuk menganalisis seberapa besar pengaruh sistem pengukuran kinerja terhadap kinerja Pegawai Bea dan Cukai dalam pengawasan peredaran rokok ilegal. b. Untuk menganalisis seberapa besar pengaruh disiplin kerja terhadap kinerja Pegawai Bea dan Cukai dalam pengawasan peredaran rokok ilegal. c. Untuk menganalisis seberapa besar pengaruh sistem pengukuran kinerja dan disiplin kerja terhadap kinerja Pegawai Bea dan Cukai dalam pengawasan peredaran rokok ilegal.

\section{KAJIAN LITERATUR}

\section{A. Pengertian sistem pengukuran kinerja}

1) Menurut Moeheriono (2017 : 96-97), pengukuran kinerja (performance measurement) adalah suatu proses penilaian tentang kemajuan pekerjaan terhadap tujuan dan sasaran dalam pengelolaan sumber daya manusia untuk menghasilkan barang dan jasa, termasuk informasi atas efisiensi serta efektivitas tindakan dalam mencapai tujuan organisasi. Beberapa aspek mendasar dan paling pokok dari pengukuran kinerja adalah:

a) Menetapkan tujuan, sasaran dan strategi organisasi, dengan menetapkan secara umum apa yang diinginkan oleh organisasi sesuai dengan tujuan, visi dan misinya.

b) Merumuskan indikator kinerja dan ukuran kinerja, yang mengacu pada penilaian kinerja secara tidak langsung, sedangkan indikator kinerja mengacu pada pengukuran kinerja secara langsung yang berbentuk keberhasilan utama (critical success factors) dan indikator kinerja kunci (key performance indicator).

c) Mengukur tingkat capaian tujuan dan sasaran organisasi, menganalisis hasil pengukuran kinerja yang dapat diimplementasikan dengan membandingkan tingkat capaian tujuan, dan sasaran organisasi. 
d) Mengevaluasi kinerja dengan menilai kemajuan organisasi dan pengambilan keputusan yang berkualitas, memberikan gambaran atau hasil kepada organisasi seberapa besar tingkat keberhasilan tersebut dan mengevaluasi langkah apa yang diambil organisasi selanjutnya.

2) Menurut Mahmudi (2015: 6), manajemen berbasis kinerja membutuhkan alat yang disebut pengukuran kinerja, yaitu alat untuk menilai sukses atau tidaknya suatu organisasi, program, atau kegiatan. Dengan kata lain, pengukuran kinerja merupakan elemen pokok manajemen berbasis kinerja. Pengukuran kinerja paling tidak harus mencakup tiga variabel penting yang harus dipertimbangkan, yaitu perilaku (proses), output (produk langsung suatu aktivitas/program), dan outcome (value added atau dampak aktivitas/program) yang saling berkaitan, saling tergantung satu dengan lainnya.

3) Menurut Sedarmayanti (2017: 219-220), pengukuran kinerja adalah alat manajemen yang digunakan untuk meningkatkan kualitas pengambilan keputusan dan akuntabilitas. Pengukuran kinerja juga digunakan untuk menilai pencapaian tujuan dan sasaran (James Whittaker, 1993). Pengukuran kinerja digunakan untuk menilai keberhasilan/kegagalan pelaksanaan kegiatan/program/kebijakan sesuai dengan sasaran dan tujuan yang telah ditetapkan dalam rangka mewujudkan misi dan visi organisasi. Pengukuran kinerja penting peranannya sebagai alat manajemen untuk:

a) Memastikan pemahaman pelaksana akan ukuran yang digunakan untuk mencapai kinerja,

b) Memastikan tercapainya rencana kinerja yang disepakati,

c) Memantau dan mengevaluasi pelaksanaan kinerja dan membandingkannya dengan rencana kerja serta melakukan tindakan untuk memperbaiki kinerja,

d) Memberi penghargaan dan hukuman yang obyektif atas kinerja pelaksana yang telah diukur sesuai sistem pengukuran kinerja yang disepakati,

e) Menjadi alat komunikasi antara karyawan dan pimpinan dalam upaya memperbaiki kinerja organisasi,

f) Mengidentifikasi apakah kepuasan pelanggan sudah terpenuhi,

g) Membantu memahami proses kegiatan organisasi,

h) Memastikan bahwa pengambilan keputusan dilakukan secara obyektif,

i) Menunjukkan peningkatan yang perlu dilakukan, dan

j) Mengungkap permasalahan yang terjadi.

4) Menurut Mohamad Mahsun, (2016: 25-26), pengukuran kinerja adalah suatu metode atau alat yang digunakan untuk mencatat dan menilai pencapaian pelaksanaan kegiatan berdasarkan tujuan, sasaran, dan strategi, sehingga dapat diketahui kemajuan organisasi serta meningkatkan kualitas pengambilan keputusan dan akuntabilitas. Elemen pokok dalam sistem pengukuran kinerja tersebut adalah: 1) Menetapkan tujuan, sasaran, dan strategi organisasi, 2) Merumuskan indikator dan ukuran kinerja, 3) Mengukur tingkat capaian tujuan dan sasaran organisasi, dan 4) Evaluasi kinerja untuk mengetahui kemajuan organisasi dan untuk meningkatkan kualitas keputusan dan akuntabilitas.

B. Pengertian disiplin kerja

1) Menurut Muh. Kadarisman (2018: 275), disiplin kerja Pegawai Negeri Sipil (sekarang menjadi Pegawai ASN) adalah kesanggupan Pegawai ASN untuk menaati kewajiban dan menghindari larangan yang ditentukan dalam peraturan perundang-undangan dan/atau peraturan kedinasan yang apabila tidak ditaati atau dilanggar maka dijatuhi hukuman disiplin.

2) Menurut Sedarmayanti (2017: 399), disiplin adalah kondisi untuk melakukan koreksi atau menghukum pegawai yang melanggar ketentuan atau prosedur yang telah ditetapkan organisasi. Menurutnya, disiplin merupakan bentuk pengendalian agar pelaksanaan pekerjaan pegawai selalu berada pada koridor peraturan perundang-undangan yang berlaku.

3) Menurut Roebing Gunawan Budhi (2017: 1-3), terminologi disiplin berasal dari kata latin yakni discere, yang berarti belajar atau menggenggam. Selanjutnya timbul kata disciplina, yang bermakna pengajaran atau pelatihan. Dalam bahasa Inggris, disiplin dikenal sebagai "disciple" yang bermakna pengikut atau murid. Kedisiplinan merupakan sebuah kebutuhan sekaligus tuntutan dalam berbagai sendi kehidupan sosial kemasyarakatan, khususnya masyarakat modern di semua tempat dan waktu, 
baik di institusi pendidikan, instansi pemerintah maupun swasta, hingga di berbagai area publik, seperti terminal, jalan raya, maupun di pelabuhan laut-udara. Roebing Gunawan Budhi mengutip pendapat Prof. James Drever (1910-1991), seorang filsuf dari University of Dundee, Skotlandia, bahwa disiplin adalah kemampuan mengendalikan perilaku yang berasal dari dalam diri seseorang sesuai dengan hal-hal yang telah diatur dari luar atau norma yang telah ada. Artinya, disiplin dari sudut psikologis merupakan perilaku seseorang yang muncul dan mampu menyesuaikan diri dengan aturan yang telah ditetapkan.

4) Menurut Malayu S.P. Hasibuan (2009: 193-194), kedisiplinan adalah kesadaran dan kesediaan seseorang menaati semua peraturan perusahaan dan norma-norma sosial yang berlaku. Kesadaran adalah sikap seseorang secara sukarela menaati semua peraturan dan sadar akan tugas dan tanggung jawabnya. Jadi dia akan mematuhi/mengerjakan semua tugasnya dengan baik, bukan atas paksaan. Kesediaan adalah suatu sikap, tingkah laku dan perbuatan seseorang yang sesuai dengan peraturan perusahaan, baik yang tertulis maupun tidak.

5) Menurut Soegeng Prijodarminto (1993: 23), disiplin adalah suatu kondisi yang tercipta dan terbentuk melalui proses dari serangkaian perilaku yang menunjukkan nilai-nilai ketaatan, kepatuhan, kesetiaan, keteraturan dan atau ketertiban. Disiplin mempunyai tiga aspek yaitu:

a) Sikap mental (mental attitude), yang merupakan sikap taat dan tertib sebagai hasil atau pengembangan dari latihan, pengendalian pikiran, dan pengendalian watak.

b) Pemahaman yang baik mengenai sistem aturan perilaku, norma, kriteria, dan standar yang sedemikian rupa, sehingga pemahaman tersebut menumbuhkan pengertian yang mendalam atau kesadaran, bahwa ketaatan akan aturan, norma, kriteria, dan standar merupakan syarat mutlak untuk mencapai keberhasilan (sukses).

c) Sikap kelakuan yang secara wajar menunjukkan kesungguhan hati, untuk menaati segala hal secara cermat dan tertib.

\section{Pengertian kinerja}

1) Menurut Moeheriono (2017: 95-98) kinerja (performance) adalah gambaran mengenai tingkat pencapaian pelaksanaan suatu program kegiatan atau kebijakan dalam mewujudkan sasaran, tujuan, visi dan misi organisasi yang dituangkan melalui perencanaan strategis suatu organisasi. Kinerja dapat diketahui dan diukur jika individu atau sekelompok karyawan telah mempunyai kriteria atau standar keberhasilan tolok ukur yang ditetapkan organisasi. Kinerja atau performance adalah hasil kerja yang dapat dicapai oleh seseorang atau sekelompok orang dalam suatu organisasi baik secara kuantitatif maupun kualitatif, sesuai dengan kewenangan dan tugas tanggung jawab masing-masing, dalam upaya mencapai tujuan organisasi. Arti kinerja sebenarnya berasal dari job performance dan disebut juga actual performance atau prestasi kerja atau prestasi sesungguhnya yang telah dicapai oleh seorang karyawan. Dalam suatu organisasi dikenal tiga jenis kinerja yang dapat dibedakan menjadi sebagai berikut:

a) Kinerja operasional (operational performance), kinerja ini berkaitan dengan efektivitas penggunaan setiap sumber daya yang digunakan oleh perusahaan, seperti modal, bahan baku, teknologi, dan lain-lain. Sejauh mana penggunaan tersebut secara maksimal untuk mencapai keuntungan atau mencapai visi dan misinya.

b) Kinerja administratif (administrative performance), kinerja ini berkaitan dengan kinerja administrasi organisasi. Termasuk di dalamnya struktur administratif yang mengatur hubungan otoritas wewenang dan tanggung jawab dari orang yang menduduki jabatan. Selain itu, berkaitan dengan kinerja mekanisme aliran informasi antar unit kerja dalam organisasi.

c) Kinerja stratejik (strategic performance), kinerja ini berkaitan atas kinerja perusahaan dievaluasi ketepatan perusahaan dalam memilih lingkungannya dan kemampuan adaptasi perusahaan khususnya secara strategi perusahaan dalam menjalankan visi dan misinya.

2) Menurut Mohamad Mahsun (2016: 25) kinerja (performance) adalah gambaran mengenai tingkat pencapaian pelaksanaan suatu kegiatan/program/kebijakan dalam mewujudkan sasaran, tujuan, misi dan visi organisasi yang tertuang dalam strategic planning suatu organisasi. Istilah kinerja sering 
digunakan untuk menyebut prestasi atau tingkat keberhasilan individu maupun kelompok individu. Menurutnya, kinerja bisa diketahui hanya jika individu atau kelompok individu tersebut mempunyai kriteria keberhasilan yang telah ditetapkan. Kriteria keberhasilan ini berupa tujuan-tujuan atau targettarget tertentu yang hendak dicapai.

3) Menurut Wibowo (2016: 2), performance sering diartikan sebagai kinerja, hasil kerja atau prestasi kerja. Menurutnya, kinerja mempunyai makna yang lebih luas, bukan hanya menyatakan sebagai hasil kerja, tetapi juga bagaimana proses kerja berlangsung. Kinerja adalah tentang apa yang dikerjakan dan bagaimana cara mengerjakannya. Wibowo mengutip pendapat Cascio (2013: 693) yang memandang kinerja sebagai cara untuk memastikan bahwa pekerja individual atau tim tahu apa yang diharapkan dari mereka dan mereka fokus pada kinerja efektif dengan memberikan perhatian pada tujuan, ukuran dan penilaian.

4) Mahmudi (2015: 6) mengutip beberapa pengertian kinerja, yaitu: a) pendapat Otley bahwa kinerja mengacu pada sesuatu yang terkait dengan kegiatan melakukan pekerjaan, dalam hal ini meliputi hasil yang dicapai kerja tersebut. Kinerja merupakan suatu konstruk (construct) yang bersifat multidimensional, pengukurannya juga bervariasi tergantung pada kompleksitas faktor-faktor yang membentuk kinerja; dan b) pendapat Rogers (1994) bahwa kinerja mestinya didefinisikan sebagai hasil kerja itu sendiri (outcomes of work), karena hasil kerja memberikan keterkaitan yang kuat terhadap tujuan-tujuan stratejik organisasi, kepuasan pelanggan, dan kontribusi ekonomi.

Dari kajian pustaka tersebut, peneliti merumuskan kerangka teori dan hipotesis sebagai berikut:

A. Sistem pengukuran kinerja berpengaruh terhadap kinerja Pegawai Bea dan Cukai dalam pengawasan peredaran rokok ilegal. Sistem pengukuran kinerja yang baik memiliki dimensi:

1) Dimensi standar dan ukuran kinerja, bahwa Pegawai Bea dan Cukai baik secara individu maupun kelompok individu memiliki standar dan ukuran kinerja yang menjadi tolok ukur keberhasilan dalam melaksanakan pengawasan peredaran rokok ilegal.

2) Dimensi tingkat capaian kinerja, bahwa kinerja Pegawai Bea dan Cukai baik secara individu maupun kelompok individu dalam melaksanakan pengawasan peredaran rokok ilegal akan diukur tingkat capaiannya secara periodik berdasarkan sasaran dan tujuan yang telah ditentukan.

3) Dimensi evaluasi capaian kinerja, bahwa kinerja Pegawai Bea dan Cukai baik secara individu maupun kelompok individu dalam mencapai sasaran dan tujuan pengawasan peredaran rokok ilegal akan dievaluasi secara periodik untuk mengetahui kemajuan organisasi, dan untuk meningkatkan kualitas keputusan dan akuntabilitas, termasuk memetakan hambatan dan memutuskan rencana aksi yang akan dilakukan untuk mengantisipasi hambatan yang akan terjadi.

B. Disiplin kinerja berpengaruh terhadap kinerja Pegawai Bea dan Cukai dalam pengawasan peredaran rokok ilegal. Disiplin kinerja yang baik memiliki dimensi:

1) Dimensi kesadaran, bahwa Pegawai Bea dan Cukai memiliki pemahaman yang baik terhadap sistem aturan perilaku, norma, kriteria, dan standar yang berlaku, sehingga menumbuhkan kesadaran, bahwa ketaatan terhadap aturan, norma, kriteria, dan standar merupakan syarat mutlak untuk mencapai keberhasilan (sukses).

2) Dimensi patuh terhadap kewajiban, bahwa Pegawai Bea dan Cukai sanggup untuk patuh agar selalu berada pada koridor peraturan perundang-undangan dan/atau peraturan kedinasan yang berlaku.

3) Dimensi menghindari larangan, bahwa Pegawai Bea dan Cukai berupaya menghindari larangan yang telah ditentukan dalam peraturan perundang-undangan dan/atau peraturan kedinasan, yang apabila tidak ditaati atau dilanggar maka dijatuhi hukuman disiplin.

C. Sistem pengukuran kinerja dan disiplin kerja berpengaruh terhadap kinerja Pegawai Bea dan Cukai dalam pengawasan peredaran rokok ilegal. Kinerja yang baik memiliki dimensi:

1) Dimensi kuantitas kinerja, bahwa kinerja Pegawai Bea dan Cukai dalam Pengawasan Peredaran Rokok Ilegal diukur berdasarkan jumlah kasus penindakan rokok ilegal yang dihasilkan (activity).

2) Dimensi kualitas kinerja, bahwa kinerja Pegawai Bea dan Cukai dalam Pengawasan Peredaran Rokok Ilegal akan diukur kualitasnya yaitu berdasarkan perencanaan, pelaksanaan, penindakan, dan tindak lanjut hasil penindakan (quality). 
3) Dimensi efisiensi, bahwa kinerja Pegawai Bea dan Cukai dalam Pengawasan Peredaran Rokok Ilegal akan diukur tingkat efisiennya dalam menggunakan sumber daya organisasi.

4) Dimensi efektivitas, bahwa Pegawai Bea dan Cukai dalam Pengawasan Peredaran Rokok Ilegal akan dikukur tingkat efektivitasnya sesuai dengan visi, misi, sasaran dan tujuan organisasi.

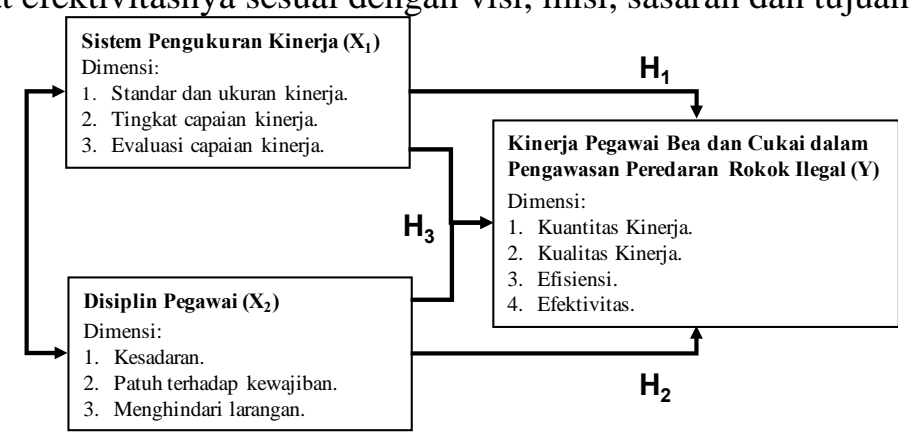

Gambar 4

Kerangka Teori

Hipotesis:

$\mathrm{H}_{1}$ ： Sistem pengukuran kinerja $\left(\mathrm{X}_{1}\right)$ secara parsial berpengaruh positif dan signifikan terhadap kinerja Pegawai Bea dan Cukai dalam pengawasan peredaran rokok ilegal (Y).

$\mathrm{H}_{2}$ : Disiplin kerja $\left(\mathrm{X}_{2}\right)$ secara parsial berpengaruh positif dan signifikan terhadap kinerja Pegawai Bea dan Cukai dalam pengawasan peredaran rokok ilegal ( $\mathrm{Y})$.

$\mathrm{H}_{3}$ : Sistem pengukuran kinerja $\left(\mathrm{X}_{1}\right)$ dan disiplin kerja $\left(\mathrm{X}_{2}\right)$ secara simultan berpengaruh positif dan signifikan terhadap kinerja Pegawai Bea dan Cukai dalam pengawasan peredaran rokok ilegal (Y).

\section{METODE PENELITIAN}

Penelitian ini adalah penelitian kuantitatif. Penulis menggunakan metode survei dengan pendekatan deskriptif dan verifikatif. Populasi penelitian ini adalah 3.949 orang Pegawai Bea dan Cukai yang bekerja pada unit pengawasan di seluruh Indonesia, baik di Kantor Wilayah maupun di Kantor Pengawasan dan Pelayanan Bea dan Cukai, baik pada kantor yang mengawasi daerah produksi, maupun kantor yang mengawasi daerah distribusi atau pemasaran rokok. Penulis menggunakan teknik pengambilan sampel probability sampling yaitu cluster sampling, hasilnya adalah 520 orang responden. Dengan pertimbangan biaya dan waktu, penulis memutuskan mengambil sampel lanjutan dengan rumus slovin (error margin 5\%) dan hasilnya adalah sebanyak 223 orang responden sebagai target penelitian.

Teknik pengumpulan data dalam penelitian ini menggunakan kuesioner dan dokumentasi. Penulis menyusun kuesioner yang terdiri dari 45 item pernyataan berdasarkan kisi-kisi variabel sistem pengukuran kinerja $\left(\mathrm{X}_{1}\right)$, disiplin kerja $\left(\mathrm{X}_{2}\right)$, dan kinerja Pegawai Bea dan Cukai dalam pengawasan peredaran rokok ilegal (Y). Teknik dokumentasi digunakan penulis untuk mengumpulkan data pegawai, hasil Survei Cukai Rokok Ilegal yang dilakukan UGM Yogyakarta tahun 2010-2018, data kinerja pengawasan rokok ilegal, dan data penerimaan cukai rokok.

Penulis menyebarkan kuesioner kepada 300 orang responden. Jumlah kuesioner yang kembali adalah 253 (melampaui jumlah target sampel 223 responden) dan seluruhnya telah diisi lengkap oleh responden dengan karakteristik sebagai berikut:
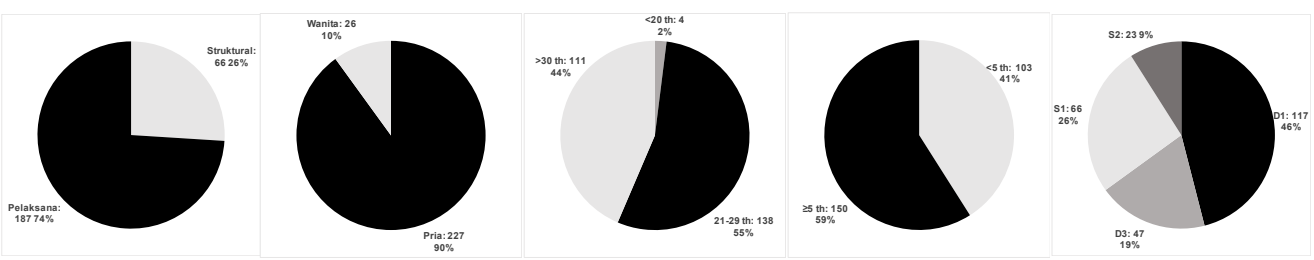

Gambar 5 Data Jabatan, Gender, Usia, Masa Kerja, dan Pendidikan Responden

Pada Gambar 5 di atas, 253 responden mempunyai karakteristik yang kuat dan mendukung penelitian baik dari faktor jabatan, gender, usia, masa kerja dan pendidikan. 
Dalam melakukan penelitian, penulis merumuskan operasionalisasi variabel sebagai berikut:

A. Sistem pengukuran kinerja $\left(X_{1}\right)$ adalah alat manajemen (Sedarmayanti, 2017: 219-220) untuk mengukur kinerja yang dapat menggambarkan tingkat capaian program kegiatan atau kebijakan yang telah dilaksanakan dalam mewujudkan tujuan dan sasaran yang ingin dicapai organisasi (Moeheriono, 2017: 96-97). Elemen pokok dalam sistem pengukuran kinerja adalah: 1) Menetapkan tujuan, sasaran, dan strategi organisasi, 2) Merumuskan indikator dan ukuran kinerja, 3) Mengukur tingkat capaian tujuan dan sasaran organisasi, dan 4) Evaluasi kinerja untuk mengetahui kemajuan organisasi dan untuk meningkatkan kualitas keputusan dan akuntabilitas (Mohamad Mahsun, 2016: 25-26).

B. Disiplin kerja $\left(\mathrm{X}_{2}\right)$ adalah kesanggupan pegawai untuk menaati kewajiban dan menghindari larangan yang apabila tidak ditaati atau dilanggar maka dijatuhi hukuman disiplin (Muh. Kadarisman, 2018: 275). Disiplin adalah pengendalian agar pegawai selalu berada pada koridor peraturan perundang-undangan yang berlaku (Sedarmayanti, 2017: 399). Disiplin terdiri dari tiga aspek, salah satunya aspek pemahaman yang baik mengenai perilaku, norma, kriteria, dan standar, sehingga menumbuhkan pengertian yang mendalam atau kesadaran, bahwa ketaatan merupakan syarat mutlak untuk mencapai keberhasilan (Soegeng Prijodarminto, 1993: 23).

C. Kinerja Pegawai Bea dan Cukai dalam pengawasan peredaran rokok ilegal (Y) adalah hasil kerja yang akan dicapai Pegawai Bea dan Cukai sesuai tugas dan tanggung jawabnya. Kinerja atau hasil kerja ditentukan berdasarkan kriteria keberhasilan berupa tujuan-tujuan dan target-target tertentu yang ingin dicapai, baik bersifat kuantitatif maupun kualitatif (Moeheriono, 2017: 95-98). Kinerja Pegawai Bea dan Cukai dalam pengawasan peredaran rokok ilegal menggambarkan seberapa jauh tugas pengawasan dilakukan secara efektif dan efisien. Artinya kinerja menjadi metode untuk memastikan bahwa Pegawai Bea dan Cukai mengerti apa yang harus dilakukan agar fokus pada hasil, dan fokus pada tujuan, ukuran, dan penilaian (Cascio dalam Wibowo, 2016: 2).

Selanjutnya, penulis menganalisis data ordinal yang diperoleh dari pengukuran skala Likert dengan menggunakan software Statistical Package for the Social Science (SPSS v.22). Teknis analisis data yang digunakan penulis dalam melakukan uji statistik adalah sebagai berikut:

A. Uji Instrumen

1) Uji validitas ( $\mathrm{r}_{\text {hitung }}$ ) setiap item pernyataan menggunakan teknik korelasi product moment dengan rumus korelasi pearson. Kriteria keputusannya adalah jika nilai $\mathrm{r}_{\text {hitung }}>$ nilai $\mathrm{r}_{\text {tabel }}$ pada $\alpha=5 \%(0,05)$ dan $\mathrm{df}=\mathrm{n}-2$, maka item pernyataan dinyatakan valid.

$$
r_{\text {hitung }}=\frac{n(\Sigma x y)-(\Sigma x) \cdot(\Sigma y)}{\sqrt{\left\{n \cdot \Sigma x^{2}-(\Sigma x)^{2}\right\} \cdot\left\{n \cdot \Sigma y^{2}-(\Sigma y)^{2}\right\}}} \quad \begin{array}{ll}
\mathrm{x}=\text { skor variabel (jawaban responden) } \\
\mathrm{n}=\text { jumlah responden }
\end{array}
$$

Gambar 6 Rumus Korelasi Pearson

2) Uji reliabilitas untuk mengukur keandalan instrumen dengan menggunakan teknik Croncbach's Alpha. Kriteria keputusannya adalah jika nilai alpha $(\boldsymbol{\alpha}) \geq 0,7$, maka instrumen ukuran tersebut mengindikasikan satisfactory internal consistency reliability.

B. Uji Asumsi Klasik

1) Uji Otokorelasi untuk mengetahui ada tidaknya hubungan antarvariabel bebas dengan variabel terikat yang tidak tepat dengan melakukan analisis statistik Durbin Watson (DW). Kriteria keputusannya adalah jika nilai DW berada antara -2 dan $2(-2 \leq \mathrm{DW} \leq 2)$, maka tidak terjadi otokorelasi.

2) Uji Normalitas untuk mengetahui apakah variabel pengganggu pada variabel bebas (residual) berdistribusi normal dengan menggunakan teknik One Sample Kolmogorov Smirnov. Kriteria keputusannya adalah dengan melihat probability asymp.sig (2-tailed). Apabila nilai probability asymp.sig > 0,05, maka data mempunyai distribusi normal

3) Uji Heteroskedasitas untuk mengetahui apakah dalam model regresi terjadi ketidaksamaan variansi dari residual suatu pengamatan ke pengamatan yang lain dengan menggunakan uji Glejser. Kriteria keputusannya adalah bahwa heteroskedastisitas terjadi jika nilai $\operatorname{sig}<\alpha 0,05$. 
4) Uji Multikolinearitas untuk mengetahui ada tidaknya korelasi di antara variabel bebas dengan melakukan analisis statistik nilai variance inflation factor (VIF) dan nilai toleransi (tolerance). Kriteria keputusannya adalah jika nilai VIF $<10$ dan nilai toleransi $>0,1$, maka tidak terjadi multikolinieritas di antara variabel bebas.

C. Analisis deskriptif yaitu mendiskripsikan karakteristik sekelompok data yang dianalisis dengan menggunakan teknik statistik untuk mengetahui data ordinal berdasarkan jawaban responden terhadap pernyataan kuesioner yang meliputi range (selisih antara nilai tertinggi dan nilai terendah), maximum (nilai tertinggi), minimum (nilai terendah), dan mean (nilai rata-rata).

D. Analisis Inferensi/Uji Hipotesis

1) Uji signifikansi simultan (uji F) untuk mengetahui apakah variabel bebas secara simultan mempengaruhi variabel terikat. Kriteria keputusannya adalah Jika nilai sig. $\leq \alpha$, maka $\mathrm{H}_{0}$ ditolak dan sebaliknya $\mathrm{H}_{\mathrm{a}}$ diterima. Hipotesis yang diuji adalah:

$\mathrm{H}_{0}$ : Sistem pengukuran kinerja $\left(\mathrm{X}_{1}\right)$ dan disiplin kerja $\left(\mathrm{X}_{2}\right)$ secara simultan tidak berpengaruh terhadap kinerja Pegawai Bea dan Cukai dalam pengawasan peredaran rokok ilegal (Y).

$\mathrm{H}_{\mathrm{a}}$ : Sistem pengukuran kinerja $\left(\mathrm{X}_{1}\right)$ dan disiplin kerja $\left(\mathrm{X}_{2}\right)$ secara simultan berpengaruh terhadap kinerja Pegawai Bea dan Cukai dalam pengawasan peredaran rokok ilegal (Y).

2) Uji signifikasi parsial (uji t) untuk menguji apakah variabel bebas secara parsial mempengaruhi variabel terikat. Kriteria keputusannya adalah jika nilai sig. $\leq \alpha$, maka $\mathrm{H}_{0}$ ditolak dan sebaliknya $\mathrm{H}_{\mathrm{a}}$ diterima. Hipotesis yang diuji adalah:

Variabel sistem pengukuran kinerja $\left(\mathrm{X}_{1}\right)$ :

$\mathrm{H}_{0}$ : Sistem pengukuran kinerja $\left(\mathrm{X}_{1}\right)$ secara parsial tidak berpengaruh terhadap kinerja Pegawai Bea dan Cukai dalam pengawasan peredaran rokok ilegal (Y).

$\mathrm{H}_{\mathrm{a}}$ : Sistem pengukuran kinerja $\left(\mathrm{X}_{1}\right)$ secara parsial berpengaruh terhadap kinerja Pegawai Bea dan Cukai dalam pengawasan peredaran rokok ilegal (Y).

Variabel disiplin kerja $\left(\mathrm{X}_{2}\right)$ :

$\mathrm{H}_{0}$ : Disiplin kerja $\left(\mathrm{X}_{2}\right)$ secara parsial tidak berpengaruh terhadap kinerja Pegawai Bea dan Cukai dalam pengawasan peredaran rokok ilegal (Y).

$\mathrm{H}_{\mathrm{a}}$ : Disiplin kerja $\left(\mathrm{X}_{2}\right)$ secara parsial berpengaruh terhadap kinerja Pegawai Bea dan Cukai dalam pengawasan peredaran rokok ilegal $(\mathrm{Y})$.

E. Analisis regresi linear berganda dengan rumus $\mathrm{Y}=a+b_{1} \mathrm{X}_{1}+b_{2} \mathrm{X}_{2}+\ldots .+b_{n} \mathrm{X}_{\mathrm{n}}$ untuk memperoleh persamaan regresi $\mathrm{Y}=a+b_{1} \mathrm{X}_{1}+b_{2} \mathrm{X}_{2}$, di mana:

$\mathrm{Y}=$ kinerja Pegawai Bea dan Cukai dalam pengawasan peredaran rokok ilegal

$a, b_{1}$ dan $b_{2}=(a)$ konstanta, $\left(b_{1}\right.$ dan $\left.b_{2}\right)$ koefisien regresi

$\mathrm{X}_{1}$ dan $\mathrm{X}_{2}=\left(\mathrm{X}_{1}\right)$ sistem pengukuran kinerja dan $\left(\mathrm{X}_{2}\right)$ disiplin kerja

F. Koefisien determinasi (KD) atau uji $\mathrm{R}^{2}$, untuk mengukur tingkat keandalan atau kemampuan model regresi dalam menjelaskan variansi variabel terikat, sehingga dapat diketahui seberapa besar pengaruh variabel bebas mempengaruhi variabel terikat. Rumus yang digunakan $\mathrm{KD}=\mathrm{R}^{2} \mathrm{x} 100 \%$. Semakin kecil nilai $\mathrm{R}^{2}$ maka semakin terbatas kemampuan variabel bebas dalam menjelaskan variansi variabel terikat, dan jika nilai $\mathrm{R}^{2}$ semakin tinggi mendekati satu, maka model regresi linear akan semakin benar dan akurat.

\section{HASIL PENELITIAN DAN PEMBAHASAN}

A. Hasil Uji Instrumen

Pada tabel product moment, jika sampel $(\mathrm{n})=253, \alpha=5 \%, \mathrm{df}=(\mathrm{n}-2)$, dan tingkat signifikansi yang digunakan adalah untuk dua arah (sig. 2-tailed), maka nilai $\mathrm{r}_{\text {tabel }}=0,1234$. Dari hasil uji validitas diperoleh nilai $r_{\text {hitung }}$ paling rendah 0,316 sehingga seluruh pernyataan dinyatakan valid karena nilai $r_{\text {hitung }}$ $>$ 0,1234. Dari hasil uji reliabilitas diperoleh nilai Croncbach's Alpha (Tabel 1) sebesar 0,924 atau $\geq 0,7$ 
sehingga instrumen dinyatakan reliabel atau konsisten. Dengan demikian kuesioner layak digunakan dan penelitian dapat dilanjutkan.

Tabel 1 Hasil Uji Croncbach's Alpha

\begin{tabular}{|rr|r|}
\hline \multicolumn{2}{|c|}{ Reliability Statistics } \\
\hline \multicolumn{2}{|c|}{ Cronbach's Alpha } & N of Items \\
\hline & 924 & \\
\hline
\end{tabular}

B. Hasil Uji Asumsi Klasik

Variabel yang diteliti seluruhnya memenuhi asumsi klasik, baik dari hasil uji otokorelasi, uji normalitas, uji heteroskedastisitas, maupun uji multikolinearitas. Dengan demikian penelitian dapat dilakukan ke tahap berikutnya. Penjelasannya adalah sebagai berikut:

1) Hasil uji otokorelasi memperoleh nilai DW sebesar 1,623 (Tabel 2) atau berada di antara 2 dan -2, sehingga tidak terjadi otokorelasi antara variabel bebas dan variabel terikat.

\begin{tabular}{l} 
Tabel 2 Hasil Uji Otokorelasi \\
\begin{tabular}{|l|cc|}
\hline \multicolumn{1}{|c|}{ Model Summary } \\
\hline Model & Durbin-Watson \\
\hline 1 & & 1,623 \\
\hline a. Predictors: (Constant), Disiplin Kerja, Sistem Pengukuran Kinerja \\
\hline $\begin{array}{l}\text { b. Dependent Variable: Kinerja Pegawai Bea dan Cukai dalam Pengawasan } \\
\text { Peredaran Rokok llegal }\end{array}$ \\
\hline
\end{tabular} \\
\hline
\end{tabular}

2) Hasil uji normalitas memperoleh nilai Asymp.Sig (2-tailed) = 0,200 atau > 0,05 (Tabel 3), sehingga seluruh data pada variabel bebas berdistribusi normal.

Tabel 3 Hasil Uji Normalitas

\begin{tabular}{|l|l|r|}
\hline \multicolumn{2}{|c|}{ One-Sample Kolmogorov-Smirnov Test } \\
\hline \multicolumn{2}{|c|}{} & Unstandardized Residual \\
\hline N & Mean & 253 \\
\cline { 2 - 3 } & Std. Deviation &, 0000000 \\
\hline \multirow{2}{*}{ Most Extreme Differences } & Absolute &, 23675236 \\
\cline { 2 - 3 } & Positive &, 048 \\
\cline { 2 - 3 } & Negative &, 048 \\
\hline \multicolumn{2}{|l|}{ Test Statistic } &,- 038 \\
\hline Asymp. Sig. (2-tailed) &, 048 \\
\hline a. Test distribution is Normal. &, $200^{c, d}$ \\
\hline b. Calculated from data. \\
\hline c. Lilliefors Significance Correction. \\
\hline d. This is a lower bound of the true significance. \\
\hline
\end{tabular}

3) Hasil uji heteroskedastisitas memperoleh nilai Sig. pada variabel sistem pengukuran kinerja $\left(X_{1}\right)$ adalah 0,315 dan nilai Sig. pada variabel disiplin kerja $\left(X_{2}\right)$ adalah 0,235 (Tabel 4), atau $>\alpha=0,05$, sehingga tidak terjadi masalah heteroskedastis.

Tabel 4 Hasil Uji Heteroskedastisitas

\begin{tabular}{|c|c|c|c|c|c|c|}
\hline \multicolumn{7}{|c|}{ Coefficients $^{a}$} \\
\hline \multirow{2}{*}{\multicolumn{2}{|c|}{ Model }} & \multicolumn{2}{|c|}{$\begin{array}{c}\text { Unstandardized } \\
\text { Coefficients }\end{array}$} & \multirow{2}{*}{$\begin{array}{c}\begin{array}{c}\text { Standardized } \\
\text { Coefficients }\end{array} \\
\text { Beta }\end{array}$} & \multirow{2}{*}{$\mathrm{t}$} & \multirow{2}{*}{ sig. } \\
\hline & & B & Std. Error & & & \\
\hline \multirow[t]{3}{*}{1} & (Constant) & 141 & 123 & & 1,146 & ,253 \\
\hline & Sistem Pengukuran Kinerja &,- 028 & 027 &,- 076 & $-1,006$ & ,315 \\
\hline & Disiplin Kerja & ,037 & ,031 & 090 & 1,190 & 235 \\
\hline
\end{tabular}

4) Hasil uji multikolinearitas, seluruh varian variabel bebas memiliki nilai VIF $=1,424$ atau $<10$ dan nilai tolerance $=0,702$ atau $>0,1$ (Tabel 5), sehingga tidak terjadi multikoliniearitas di antara kedua variabel bebas.

Tabel 5 Hasil Uji Multikolinearitas

\begin{tabular}{|c|c|c|c|c|c|c|c|c|}
\hline \multicolumn{9}{|c|}{ Coefficients $^{\mathrm{a}}$} \\
\hline \multirow{2}{*}{\multicolumn{2}{|c|}{ Model }} & \multicolumn{2}{|c|}{$\begin{array}{c}\text { Unstandardized } \\
\text { Coefficients }\end{array}$} & \multirow{2}{*}{$\begin{array}{c}\begin{array}{c}\text { Standardized } \\
\text { Coefficients }\end{array} \\
\text { Beta }\end{array}$} & \multirow{2}{*}{$\mathrm{t}$} & \multirow{2}{*}{ Sig. } & \multicolumn{2}{|c|}{$\begin{array}{l}\text { Collinearity } \\
\text { Statistics }\end{array}$} \\
\hline & & B & Std. Error & & & & Tolerance & VIF \\
\hline \multirow[t]{3}{*}{1} & (Constant) & ,275 & 191 & & 1,442 & 150 & & \\
\hline & $\begin{array}{l}\text { Sistem Pengukuran } \\
\text { Kinerja }\end{array}$ & ,265 & ,043 & 283 & 6,211 & ,000 & ,702 & 1,424 \\
\hline & Disiplin Kerja &, 652 & ,049 & 608 & 13,354 &, 000 &, 702 & 1,424 \\
\hline
\end{tabular}




\section{Hasil Analisis Deskriptif}

1) Rata-rata responden menjawab "setuju" terhadap 15 item pernyataan pada variabel sistem pengukuran kinerja $\left(\mathrm{X}_{1}\right)$. Namun demikian beberapa responden ada juga yang menjawab "sangat tidak setuju", misalnya pada pernyataan:

a) "Tugas yang saya kerjakan mempunyai target yang jelas dan terukur".

b) "Untuk mendapat nilai capaian kinerja, saya melaporkan hasil pekerjaan saya dengan menggunakan dokumen pendukung".

c) "Atasan melibatkan saya dalam rapat evaluasi kinerja".

2) Dari 13 item pernyataan pada variabel disiplin kerja $\left(\mathrm{X}_{2}\right)$, responden menjawab "setuju" terhadap 11 item pernyataan sedangkan 2 item pernyataan lainnya responden menjawab "netral" yaitu: "Saya tidak begitu peduli dengan rekan kerja saya" dan "Saya tidak begitu peduli dengan situasi kerja saya di kantor". Beberapa responden ada juga yang menjawab "sangat tidak setuju", misalnya pada pernyataan:

a) "Saya tidak begitu peduli dengan rekan kerja saya".

b) "Saya akan melaporkan kepada atasan, jika saya mengetahui terjadinya atau akan terjadinya perbuatan yang merugikan organisasi".

c) "Saya tidak begitu peduli dengan situasi kerja saya di kantor".

3) Dari 17 item pernyataan pada variabel kinerja Pegawai Bea dan Cukai dalam pengawasan peredaran rokok ilegal (Y), responden menjawab "setuju" terhadap 15 item pernyataan sedangkan 2 item pernyataan lainnya responden menjawab "netral" yaitu: "Atasan tidak pernah menanyakan laporan hasil pelaksanaan tugas pengawasan" dan "Atasan tidak peduli dengan kendala operasional yang saya hadapi saat melaksanakan tugas pengawasan". Beberapa responden ada juga yang menjawab "sangat tidak setuju", misalnya pada pernyataan:

a) "Saya melaksanakan tugas pengawasan minimal sekali dalam satu bulan".

b) "Atasan membagi tugas pengawasan kepada bawahannya secara berkelompok, bukan perorangan".

c. "Atasan tidak peduli dengan kendala operasional yang saya hadapi saat melaksanakan tugas pengawasan".

\section{Hasil Analisis Inferensi (Uji Hipotesis)}

1) Hasil uji signifikansi simultan (uji F) memperoleh nilai sig. $=0,000$ atau $\leq \alpha=0,05$ (Tabel 6), sehingga $\mathrm{H}_{0}$ ditolak dan $\mathrm{H}_{\mathrm{a}}$ diterima, artinya sistem pengukuran kinerja $\left(\mathrm{X}_{1}\right)$ dan disiplin kerja $\left(\mathrm{X}_{2}\right)$ secara simultan berpengaruh terhadap kinerja Pegawai Bea dan Cukai dalam pengawasan peredaran rokok ilegal $(\mathrm{Y})$. Uji $\mathrm{F}$ juga dilakukan dengan membandingkan nilai $\mathrm{F}_{\text {hitung }}$ terhadap nilai $\mathrm{F}_{\text {tabel }}$ pada $\alpha=0,05$. Jika nilai $\mathrm{F}_{\text {hitung }}>$ nilai $\mathrm{F}_{\text {tabel }}$ maka $\mathrm{H}_{0}$ ditolak dan $\mathrm{H}_{\mathrm{a}}$ diterima. Pada Tabel 6 diketahui nilai $\mathrm{F}_{\text {hitung }}=218,818$ atau $>$ nilai $\mathrm{F}_{\text {tabel }}=3,032$, dengan demikian $\mathrm{H}_{\mathrm{a}}$ diterima, bahwa sistem pengukuran kinerja $\left(\mathrm{X}_{1}\right)$ dan disiplin kerja $\left(\mathrm{X}_{2}\right)$ secara simultan berpengaruh terhadap kinerja Pegawai Bea dan Cukai dalam pengawasan peredaran rokok ilegal (Y).

Tabel 6 Hasil Uji F (Anova)

\begin{tabular}{|c|c|c|c|c|c|c|}
\hline \multicolumn{7}{|c|}{ ANOVA $^{a}$} \\
\hline \multicolumn{2}{|c|}{ Model } & \multirow{2}{*}{$\begin{array}{r}\text { Sum of Squares } \\
24,726\end{array}$} & \multirow{2}{*}{$\frac{\mathrm{df}}{2}$} & \multirow{2}{*}{$\begin{array}{r}\text { Mean Square } \\
12,363\end{array}$} & \multirow{2}{*}{\begin{tabular}{c|}
$F$ \\
218,818
\end{tabular}} & \multirow{2}{*}{$\begin{array}{l}\text { Sig. } \\
, 000^{\mathrm{b}}\end{array}$} \\
\hline 1 & Regression & & & & & \\
\hline & Residual & 14,125 & 250 & ,057 & & \\
\hline & Total & 38,852 & 252 & & & \\
\hline \multicolumn{7}{|c|}{ a. Dependent Variable: Kinerja Pegawai Bea dan Cukai dalam Pengawasan Peredaran Rokok Ilegal } \\
\hline & & 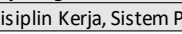 & & Kinerja & & \\
\hline
\end{tabular}

2) Hasil uji signifikansi parsial (uji t) memperoleh nilai sig. pada masing-masing variabel bebas $=0,000$ $(\leq \alpha: 0,05)$, sehingga $\mathrm{H}_{0}$ ditolak dan $\mathrm{H}_{\mathrm{a}}$ diterima (Tabel 7). Uji hipotesis juga dilakukan dengan membandingkan nilai $t_{\text {hitung }}$ terhadap nilai $t_{\text {tabel }}$ pada $\alpha=0,05$. Jika nilai $t_{\text {hitung }}>$ nilai $t_{\text {tabel }}$ maka $\mathrm{H}_{0}$ ditolak dan $\mathrm{H}_{\mathrm{a}}$ diterima. Pada Tabel 7 diketahui nilai $t_{\text {hitung }}$ variabel sistem pengukuran kinerja $\left(\mathrm{X}_{1}\right)$ 
$=6,211$, dan variabel disiplin kerja $\left(\mathrm{X}_{2}\right)=13,354$. Nilai thitung kedua variabel bebas tersebut $>$ nilai $\mathrm{t}_{\text {tabel }}=1$,969. Dengan demikian $\mathrm{H}_{0}$ ditolak dan $\mathrm{H}_{\mathrm{a}}$ diterima, yang berarti bahwa:

a) Sistem pengukuran kinerja $\left(\mathrm{X}_{1}\right)$ secara parsial berpengaruh positif terhadap kinerja Pegawai Bea dan Cukai dalam pengawasan peredaran rokok ilegal (Y).

b) Disiplin kerja $\left(\mathrm{X}_{2}\right)$ secara parsial berpengaruh positif terhadap kinerja Pegawai Bea dan Cukai dalam pengawasan peredaran rokok ilegal $(\mathrm{Y})$.

Tabel 7 Hasil Uji t

\begin{tabular}{|c|c|c|c|c|c|c|}
\hline \multicolumn{7}{|c|}{ Coefficients $^{\mathrm{a}}$} \\
\hline \multirow{2}{*}{\multicolumn{2}{|c|}{ Model }} & \multicolumn{2}{|c|}{$\begin{array}{l}\text { Unstandardized } \\
\text { Coefficients }\end{array}$} & \multirow{2}{*}{$\begin{array}{c}\text { Standardized } \\
\text { Coefficients } \\
\text { Beta }\end{array}$} & \multirow[t]{2}{*}{$\mathrm{t}$} & \multirow[t]{2}{*}{ Sig. } \\
\hline & & B & Std. Error & & & \\
\hline \multirow[t]{3}{*}{1} & (Constant) & ,275 & 191 & & 1,442 & 150 \\
\hline & Sistem Pengukuran Kinerja & ,265 & ,043 & ,283 & 6,211 &, 000 \\
\hline & Disiplin Kerja & ,652 & 049 & ,608 & 13,354 &, 000 \\
\hline
\end{tabular}

E. Pada hasil uji $t$ (Tabel 7), nilai konstata (a) $=0,275$, dan koefisien regresi $\left(b_{1}\right)=0,265$ dan $\left(b_{2}\right)=0,652$, sehingga diperoleh persamaan regresi linear berganda: $Y=0,275+0,265 X_{1}+0,652 X_{2}$. Hal tersebut menunjukkan bahwa:

1) Jika variabel sistem pengukuran kinerja $\left(X_{1}\right)$ dan variabel disiplin kerja $\left(X_{2}\right)$ tidak ada atau koefisien regresinya nol, maka variabel kinerja Pegawai Bea dan Cukai dalam pengawasan peredaran rokok ilegal (Y) tetap akan meningkat 0,275 satuan.

2) Variabel sistem pengukuran kinerja $\left(X_{1}\right)$ mempunyai hubungan positif dan berpengaruh meningkatkan variabel kinerja Pegawai Bea dan Cukai dalam pengawasan peredaran rokok ilegal (Y) sebesar 0,265 satuan, dengan asumsi variabel lainnya konstan.

3) Variabel disiplin kerja $\left(\mathrm{X}_{2}\right)$ mempunyai hubungan positif dan berpengaruh meningkatkan variabel kinerja Pegawai Bea dan Cukai dalam pengawasan peredaran rokok ilegal (Y) sebesar 0,652 satuan, dengan asumsi variabel lainnya konstan.

F. Hasil uji $\mathrm{R}^{2}$ (koefisien determinasi) memperoleh nilai $\mathrm{R}^{2}$ sebagai berikut:

1) Nilai $R^{2}$ variabel sistem pengukuran kinerja $\left(X_{1}\right)=0,377$ (Tabel 8), artinya secara parsial variabel tersebut mampu menjelaskan variabel kinerja Pegawai Bea dan Cukai dalam pengawasan peredaran rokok ilegal (Y) sebesar 37,7\%.

Tabel 8 Hasil Uji $\mathrm{R}^{2}$ Variabel $\mathrm{X}_{1}$

\begin{tabular}{|c|c|c|c|c|c|c|c|c|c|}
\hline \multicolumn{10}{|c|}{ Model Summary ${ }^{b}$} \\
\hline \multirow[b]{2}{*}{ Model } & \multirow[b]{2}{*}{$\mathrm{R}$} & \multirow[b]{2}{*}{ R Square } & \multirow[b]{2}{*}{$\begin{array}{l}\text { Adjusted } \\
\text { R Square }\end{array}$} & \multirow[b]{2}{*}{$\begin{array}{l}\text { Std. Error } \\
\text { of the Estimate }\end{array}$} & \multicolumn{5}{|c|}{ Change Statistics } \\
\hline & & & & & $\begin{array}{l}\text { R Square } \\
\text { Change }\end{array}$ & F Change & df1 & df2 & $\begin{array}{c}\text { Sig. F } \\
\text { Change }\end{array}$ \\
\hline 1 &, $614^{\mathrm{a}}$ & ,377 & ,375 & ,31051 & ,377 & 151,952 & 1 & 251 & ,000 \\
\hline
\end{tabular}

2) Nilai $R^{2}$ variabel disiplin kerja $\left(X_{2}\right)=0,580$ (Tabel 9), artinya secara parsial variabel tersebut mampu menjelaskan variabel kinerja Pegawai Bea dan Cukai dalam pengawasan peredaran rokok ilegal (Y) sebesar $58,0 \%$.

Tabel 9 Hasil Uji $\mathrm{R}^{2}$ Variabel $\mathrm{X}_{2}$

\begin{tabular}{|c|c|c|c|c|c|c|c|c|c|}
\hline \multicolumn{10}{|c|}{ Model Summary ${ }^{b}$} \\
\hline \multirow[b]{2}{*}{ Model } & \multirow[b]{2}{*}{$\mathrm{R}$} & \multirow[b]{2}{*}{ R Square } & \multirow[b]{2}{*}{$\begin{array}{l}\text { Adjusted } \\
\text { R Square }\end{array}$} & \multirow[b]{2}{*}{$\begin{array}{l}\text { Std. Error } \\
\text { of the Estimate }\end{array}$} & \multicolumn{5}{|c|}{ Change Statistics } \\
\hline & & & & & \begin{tabular}{c|} 
R Square \\
Change
\end{tabular} & F Change & df1 & df2 & $\begin{array}{c}\text { Sig. F } \\
\text { Change }\end{array}$ \\
\hline 1 &, $762^{\mathrm{a}}$ &, 580 &, 579 & ,25487 &, 580 & 347,106 & 1 & 251 & 000 \\
\hline
\end{tabular}

3) Nilai $R^{2}$ variabel sistem pengukuran kinerja $\left(X_{1}\right)$ dan variabel disiplin kerja $\left(X_{2}\right)=0,636$ (Tabel 10), artinya kedua variabel tersebut secara simultan mampu menjelaskan variabel kinerja Pegawai Bea dan Cukai dalam pengawasan peredaran rokok ilegal (Y) sebesar $63,6 \%$, sedangkan sisanya $36,4 \%$ ditentukan oleh variabel lain yang tidak diteliti dalam penelitian ini. 
Tabel 10 Hasil Uji $\mathrm{R}^{2}$ Variabel $\mathrm{Y}$

\begin{tabular}{|c|c|c|c|c|c|c|c|c|c|}
\hline \multicolumn{10}{|c|}{ Model Summary ${ }^{\mathrm{b}}$} \\
\hline \multirow[b]{2}{*}{ Model } & \multirow[b]{2}{*}{$\mathrm{R}$} & \multirow[b]{2}{*}{ R Square } & \multirow[b]{2}{*}{$\begin{array}{l}\text { Adjusted } \\
\text { R Square }\end{array}$} & \multirow[b]{2}{*}{$\begin{array}{l}\text { Std. Error } \\
\text { of the Estimate }\end{array}$} & \multicolumn{5}{|c|}{ Change Statistics } \\
\hline & & & & & $\begin{array}{l}\text { R Square } \\
\text { Change }\end{array}$ & F Change & df1 & $\mathrm{df} 2$ & $\begin{array}{l}\text { Sig. F } \\
\text { Change }\end{array}$ \\
\hline 1 & ,798 & ,636 & 634 & 23770 & ,636 & 218,818 & 2 & 250 & ,000 \\
\hline
\end{tabular}

Berdasarkan jurnal penelitian terdahulu, kajian pustaka, dan hasil penelitian dari uji statistik tersebut di atas, peneliti menyampaikan hasil pembahasan sebagai berikut:

A. Sistem pengukuran kinerja secara parsial mempunyai hubungan dan berpengaruh positif terhadap kinerja Pegawai Bea dan Cukai dalam pengawasan peredaran rokok ilegal dengan nilai koefisien regresi 0,265 dan nilai koefisien determinasi (uji $\mathrm{R}^{2}$ ) sebesar 37,7\%. Rokok ilegal adalah rokok yang melanggar hukum UU Cukai, modus operandi pelanggarannya antara lain rokok yang beredar tanpa dilekati pita cukai (rokok polos), dilekati pita cukai palsu, atau dilekati pita cukai namun tidak sesuai peruntukannya, intinya rokok ilegal tersebut dijual secara bebas tanpa membayar cukai. Angka persentase rokok ilegal adalah hasil Survei Cukai Rokok Ilegal yang dilakukan UGM Yogyakarta yang dihitung dengan membandingkan jumlah rokok ilegal dan jumlah rokok yang ditemukan (persentase non-compliances), yang merepresentasikan tingkat peredaran rokok ilegal secara nasional. Dari survei yang dilakukan setiap dua tahun sekali selama periode tahun 2010-2016 (Gambar 2), persentase rokok ilegal tersebut terus meningkat dari $6,14 \%, 8,48 \%, 11,73 \%$, dan $12,14 \%$. Untuk menanggulangi hal tersebut, pada tahun 2017 DJBC menetapkan kebijakan strategis antara lain spot check dan penindakan, dan menggunakan Indikator Kinerja Utama (IKU) "Persentase Keberhasilan Pengawasan Peredaran Barang Kena Cukai Ilegal" pada Kontrak Kinerja Direktur Jenderal, Direktur Penindakan dan Penyidikan, dan semua pimpinan kantor, bukan hanya kantor yang mengawasi produksi rokok namun juga kantor yang mengawasi distribusi dan pemasaran rokok. Dengan demikian survei tahun 2018 menjadi hal penting untuk mengetahui sejauh mana tingkat peredaran rokok ilegal masih terjadi.

Survei Cukai Rokok Ilegal Tahun 2018, UGM, Yogyakarta menggunakan metode yang sama dengan survei tahun 2016, yaitu stratified random sampling secara bertahap mulai dari level provinsi (29), kabupaten/kota (426), sampai level desa (70.198). Data populasi distratifikasi berdasarkan tingkat konsumsi rokok high, medium, dan low, dan diperoleh 106 kabupaten/kota dengan tingkat konsumsi rokok high, 213 kabupaten/kota dengan tingkat konsumsi rokok medium, dan 107 kabupaten/kota dengan tingkat konsumsi rokok low. Hasil random sampling tersebut adalah 292 desa yang kemudian dipilih menjadi sampel penelitian pada 16 Provinsi dan 73 Kabupaten/Kota. Pengambilan sampel dilakukan oleh surveyor dengan cara membeli rokok pada toko/kios/warung dan penjual eceran. Hasil survei tahun 2018 bahwa persentase non-compliances secara nasional sebesar 7,04\%, artinya dari 100 bungkus rokok yang ditemukan terdapat 7,04 bungkus rokok yang melanggar UU Cukai. Dengan asumsi stock turnover adalah 73 kali dalam setahun (restock rokok dilakukan toko/warung setiap 5 hari sekali), maka akan berpotensi turunnya penerimaan cukai rokok dalam setahun minimal Rp.1.276.729.804.240.

Berdasarkan hasil survei tahun 2018, penulis berpendapat bahwa sistem pengukuran kinerja yang menggunakan IKU "Persentase Keberhasilan Pengawasan Peredaran Barang Kena Cukai Ilegal” pada tahun 2017 telah memberi pengaruh positif terhadap kinerja Pegawai Bea dan Cukai dalam menurunkan angka persentase rokok ilegal dari 12,14\% di tahun 2016 menjadi 7,04\% tahun 2018. Namun demikian sistem pengukuran kinerja tersebut masih perlu dioptimalkan untuk menurunkan persentase rokok ilegal pada angka yang lebih rendah dari 7,04\%, karena semakin rendah angka persentase rokok ilegal maka semakin rendah potensi risiko turunnya penerimaan cukai rokok, dan akan mendorong pertumbuhan cukai rokok sebagaimana terjadi pada periode tahun 2016-2018 dari Rp.137.969.225.430.000, Rp.147.719.216.343.096, dan Rp. 152.941.398.531.293 (rata-rata pertumbuhan 5,30\%).

Penulis berpendapat bahwa IKU "Persentase Keberhasilan Pengawasan Peredaran Barang Kena Cukai Ilegal" masih menggunakan standar dan pengukuran kinerja operasional yaitu kinerja yang berkaitan dengan penggunaan sumber daya seperti modal, bahan baku, teknologi, dan lain-lain (Moeheriono, 2017: 98) sehingga hanya berorientasi pada kinerja output dan fokus pada target-target yang bersifat kuantitas, misalnya perencanaan kegiatan dan pelaksanaan pengawasan, jumlah kasus pelanggaran dan tindak lanjut. Standar dan pengukuran IKU tersebut sudah seharusnya diubah menjadi kinerja strategis yang berorientasi pada kinerja outcomes dan impact, dan mengukur langsung sejauh mana turunnya persentase rokok ilegal dan meningkatnya penerimaan cukai rokok. Hal tersebut sesuai pendapat: 
1) Moeheriono (2017: 95) bahwa kinerja adalah gambaran mengenai tingkat pencapaian pelaksanaan suatu program kegiatan atau kebijakan dalam mewujudkan sasaran, tujuan, visi dan misi organisasi yang dituangkan melalui perencanaan strategis suatu organisasi.

2) Armstrong et al. dalam Wibowo (2016: 2) bahwa kinerja merupakan hasil pekerjaan yang mempunyai hubungan kuat dengan tujuan strategis organisasi, kepuasan konsumen dan memberikan kontribusi ekonomi.

B. Disiplin kerja secara parsial mempunyai hubungan positif dan berpengaruh signifikan terhadap kinerja Pegawai Bea dan Cukai dalam pengawasan peredaran rokok ilegal, dengan nilai koefisien regresi sebesar 0,652 dan nilai koefisien determinasi (uji $\mathrm{R}^{2}$ ) sebesar 58,0\%. Penulis berpendapat bahwa disiplin kerja Pegawai Bea dan Cukai sudah sangat baik. Hal tersebut harus dipertahankan bahkan ditingkatkan DJBC, karena semakin tinggi disiplin kerja maka semakin tinggi kinerja Pegawai Bea dan Cukai dalam pengawasan peredaran rokok ilegal. Penegakan disiplin kerja yang dilakukan DJBC akan membuat setiap pekerjaan selalu berada pada koridor peraturan perundang-undangan yang berlaku Sedarmayanti (2017: 399). Dengan menerapkan nilai-nilai organisasi akan membentuk perilaku pegawai dan budaya organisasi yang semakin baik, dan disiplin kerja akan menjadi sebuah kebutuhan organisasi (Roebing Gunawan Budhi, 2017: 1-3).

C. Sistem Pengukuran Kinerja dan disiplin kerja secara simultan mempunyai hubungan positif dan berpengaruh signifikan terhadap kinerja Pegawai Bea dan Cukai dalam pengawasan peredaran rokok ilegal. Besarnya pengaruh kedua variabel bebas tersebut berdasarkan koefisien determinasi (uji $\mathrm{R}^{2}$ ) adalah $63,6 \%$ sedangkan sisanya $36,4 \%$ ditentukan oleh variabel lain yang tidak diteliti dalam penelitian ini. Penulis berpendapat bahwa nilai koefisien regresi variabel disiplin kerja sebesar 0,625 menggambarkan kondisi Pegawai Bea dan Cukai yang bekerja pada unit pengawasan memahami bahwa disiplin kerja adalah faktor keberhasilan tugas pengawasan peredaran rokok ilegal, sehingga disiplin kerja dilakukan dengan penuh kesadaran, patuh terhadap peraturan, berintegritas dan menghindari setiap hal yang dilarang karena dapat merugikan organisasi. Hal tersebut sesuai pendapat:

1) Soegeng Prijodarminto (1993: 23) bahwa disiplin memiliki 3 aspek, salah satunya aspek pemahaman yang baik mengenai sistem aturan perilaku, norma, kriteria, dan standar yang sedemikian rupa, sehingga pemahaman tersebut menumbuhkan pengertian yang mendalam atau kesadaran, bahwa ketaatan akan aturan, norma, kriteria, dan standar merupakan syarat mutlak untuk mencapai keberhasilan.

2) Malayu S.P. Hasibuan (2015: 193-194) bahwa kedisiplinan adalah kesadaran dan kesediaan seseorang menaati semua peraturan perusahaan dan norma-norma sosial yang berlaku. Kesadaran adalah sikap seseorang secara sukarela menaati semua peraturan dan sadar akan tugas dan tanggung jawabnya. Jadi dia akan mematuhi/mengerjakan semua tugasnya dengan baik, bukan atas paksaan. Kesediaan adalah suatu sikap, tingkah laku dan perbuatan seseorang yang sesuai dengan peraturan perusahaan, baik yang tertulis maupun tidak.

\section{KESIMPULAN}

Penulis menyimpulkan sebagai berikut:

A. Sistem pengukuran kinerja secara parsial berpengaruh positif dan signifikan terhadap kinerja Pegawai Bea dan Cukai dalam pengawasan rokok ilegal, dan pengaruhnya adalah sebesar 37,7\%.

B. Disiplin kerja secara parsial berpengaruh positif dan signifikan terhadap kinerja Pegawai Bea dan Cukai dalam pengawasan rokok ilegal, dan pengaruhnya adalah sebesar $58,0 \%$.

C. Sistem pengukuran kinerja dan disiplin kerja secara simultan berpengaruh positif dan signifikan terhadap kinerja Pegawai Bea dan Cukai dalam pengawasan rokok ilegal, dan pengaruhnya adalah sebesar 63,6\% sedangkan sisanya 36,4\% ditentukan oleh variabel lain yang tidak diteliti dalam penelitian ini.

Berdasarkan kesimpulan di atas, penulis menyarankan sebagai berikut:

A. Sistem pengukuran kinerja sebaiknya ditingkatkan dengan cara menyempurnakan ukuran dan target kinerja organisasi dan individu agar lebih tepat dan berorientasi pada visi, misi, tujuan, dan sasaran organisasi. 
B. Disiplin kerja Pegawai Bea dan Cukai sebaiknya dipertahankan bahkan ditingkatkan dengan cara membangun kepedulian di antara sesama Pegawai Bea dan Cukai untuk saling mengingatkan dalam mematuhi ketentuan jam kantor, kode etik, disiplin, dan perilaku.

C. Kinerja Pegawai Bea dan Cukai dalam pengawasan peredaran rokok ilegal sebaiknya ditingkatkan dengan cara mendistribusikan tugas dan tanggung jawab secara proporsional kepada setiap pegawai dalam satu tim kerja pengawasan.

\section{REFERENSI}

Ariefianto, Moch. Doddy. 2012. Ekonometrika, Esensi dan Aplikasi Menggunakan EVIEWS. Jakarta. Erlangga.

Arikunto, Suharsimi. 2013. Prosedur Penelitian, Suatu Pendekatan Praktik. Jakarta. Rineka Cipta.

Arliman, S. Laurensius. 2015. Penegakan Hukum Dan Kesadaran Masyarakat. Yogyakarta. Deepublish.

Batjo, Nurdin dan Mahadin Shaleh. 2018. Manajemen Sumber Daya Manusia. Makassar. Penerbit Aksara Timur.

Budhi, Roebing Gunawan. 2017. Revolusi Karyawan (Menjadi SDM yang Disiplin \& Produktif). Jakarta. Elex Media Komputindo.

Fahmi, Irfan. 2015. Pengantar Ilmu Administrasi Bisnis. Bandung. Alfabeta.

Handoko, T. Hani. 1995. Manajemen Edisi 2. Yogyakarta. BPFE-Yogyakarta.

Haryadi, Hendi. 2009. Administrasi Perkantoran untuk Manajer \& Staf. Jakarta. Visimedia.

Hasibuan, S.P. Malayu. 2009. Manajemen Sumber Daya Manusia, Edisi Revisi. Jakarta. Bumi Aksara.

Helmi, Avin Fadilla. 1996. Disiplin Kerja. (Buletin Psikologi, Tahun IV, Nomor 2, Desember 1996, Edisi Khusus Ulang Tahun XXXII, ISSN : 0854-7108). Yogyakarta. Fakultas Psikologi Universitas Gajah Mada.

Kadarisman, Muh. 2018. Manajemen Aparatur Sipil Negara. Depok. Rajawali Pers.

Mahmudi. 2015. Manajemen Kinerja Sektor Publik. Yogyakarta. Unit Penerbit Sekolah Tinggi Ilmu Manajemen YKPN.

Mahsun, Mohamad. 2016. Pengukuran Kinerja Sektor Publik. Yogyakarta. BPFE-Yogyakarta.

Manullang, M. 2015. Dasar-dasar Manajemen. Yogyakarta. Gajah Mada University Press.

Marmoah, Sri. 2016. Administrasi dan Supervisi Pendidikan Teori dan Praktik. Yogyakarta. Penerbit Deepublish.

Moeheriono, 2017. Pengukuran Kinerja Berbasis Kompetensi. Depok. Rajawali Pers.

Mukhlis, Suhardi. 2012. Administrasi Kepegawaian. Yogyakarta. Leutika Nouvalitera.

Mulyadi, Mohammad. 2010. Penelitian Kuantitatif \& Kualitatif, Serta Praktik Kombinasinya Dalam Penelitian Sosial. Jakarta. Publica Institute.

Prijodarminto, Soegeng. 1993. Disiplin, Kiat Menuju Sukses. Jakarta. Pradnya Paramita.

Rohman, Abd, 2018. Dasar-dasar Manajemen Publik. Malang. Empatdua Kelompok Intrans Publishing.

Rukajat, Ajat. 2018. Pendekatan Penelitian Kuantitatif (Quantitative Research Approach). Yogyakarta. Deepublish.

Sarwono, Jonathan. 2013. Strategi Melakukan Riset (Kuantitatif, Kualitatif, Gabungan). Yogyakarta. Andi Ofset.

Saydam, Gouzali. 2000. Manajemen Sumber Daya Manusia (Human Resources Management) Suatu Pendekatan Mikro. Jakarta. Djambatan.

Sedarmayanti. 2017. Manajemen Sumber Daya Manusia, Reformasi Birokrasi dan Manajemen Pegawai Negeri Sipil. Bandung. Refika Aditama.

Silalahi, Ulber. 2015. Metode Penelitian Sosial Kuantitatif. Bandung. Refika Aditama.

Siregar, Syofian. 2017. Metode Penelitian Kuantitatif. Dilengkapi dengan Perbandingan Perhitungan Manual \& SPSS. Jakarta. Kencana.

Soekanto, Soerjono. 2018. Faktor-Faktor yang Mempengaruhi Penegakan Hukum. Depok. Rajawali Press

Sugiyono. 2014. Metode Penelitian Kuantitatif, Kualitatif, dan R\&D. Bandung. Alfabeta.

Abbas Mansyur, et.al (Pengaruh Sistem Pengukuran Kinerja dan Disiplin Kerja ...) 
Sulaksono, Hari. 2015. Budaya Organisasi dan Kinerja. Yogyakarta. Deepublish.

Sukarna. 1992. Dasar-dasar Manajemen. Bandung. Mandar Maju.

Sulistiyani, Ambar Teguh dan Rosidah. 2018. Manajemen Sumber Daya Manusia, Pendekatan Teoretik dan Praktik untuk Organisasi Publik. Yogyakarta. Gava Media.

Terry, George R. dan Leslie W. Rue. (Diterjemahkan oleh G.A. Ticoalu). 2000. Dasar-dasar Manajemen. Jakarta. Remaja Rosdakarya.

Viswandro et al. 2015. Mengenal Profesi Penegak Hukum. Yogyakarta. Medpres Digital

Wibowo. 2016. Manajemen Kinerja. Jakarta. Rajawali Pers.

Yusuf, A. Muri. 2017. Metode Penelitian: Kuantitatif, Kualitatif, dan Penelitian Gabungan. Jakarta. Kencana. 